ADAM KAGAN

DOI: $10.30858 /$ zer/83033

WOJCIECH ZIETTARA

Institute of Agricultural and Food Economics

- National Research Institute

Warsaw

\title{
ECONOMIC EFFICIENCY OF FARMING - LESSEE OR OWNER (AN ATTEMPT AT ASSESSMENT)
}

\begin{abstract}
The paper presents the role and importance of land lease in structural changes in agriculture and its relations to efficiency of farming. It was demonstrated that land lease was a more efficient and cheaper method of increasing farm area (production scale) than land purchase. Research was held on selected limited liability companies using leased land ( $1^{\text {st }}$ group) and own land ( $2^{\text {nd }}$ group), and participating in the "Ranking 300" run by the Institute of Agricultural and Food Economics - National Research Institute between 2009 and 2014. Research results showed that farms run by lessees reached higher Return on Equity and Value Creation Index. The differences were not statistically confirmed, which meant that they were not significant. On the other hand, farms using own land have shown a higher level of financial security, as evidenced by higher values of liquidity ratios (current and quick) and cash flow-to-debt ratio. The hypothesis that "the lessee is more efficient than the owner" was not fully confirmed.
\end{abstract}

Keywords: farm, land lease, economic efficiency, financial security.

JEL codes: Q12, Q14, Q19. 


\section{Introduction}

All countries with market economies are characterised by a diversified pace of changes in costs of use of agricultural production factors and prices of agricultural products sold by farmers. In Poland in 1995-2015, it was the cost of labour in the national economy, with remuneration being its basic component that showed the highest dynamics. In the period under analysis they increased about 5.5 times. Despite the fact that remuneration in the national economy does not translate directly into remuneration in agriculture, they give grounds for defining parity revenue ${ }^{1}$, thus providing an assessment of revenue of farmers from their work. In the period under analysis, prices of means of production purchased by farmers increased a little more than three times, while prices of products sold by farmers - more than doubled. The price scissors indicator in the period under analysis amounted to ca. $70 \%$, which means that the pace of price increase of means of production purchased by farmers (thus the costs) was ca. $30 \%$ faster than the pace of price increase of agricultural products sold by farmers. The price of means of production growing at a faster pace than prices of agricultural products leads to decreasing unit profitability of agricultural production (Ziętara, 2016). A farmer wishing to draw a satisfactory income from a farm, at least at the parity level, must increase economic productivity of labour defined by the value of agricultural production per unit of labour output. This could be achieved by increasing the scale or intensity of production, or the area of agricultural land. The first method has a limited application, due to the existing barrier of demand for agricultural products, as well as environment protection $^{2}$. The realistic manner of increasing the scale of production is to increase farmed area, which can be done by buying or leasing land. The experience of Western European countries so far has shown that the dominating manner of increasing the area of agricultural land is a lease.

In 2000-2010, the share of leased land in Western European countries ranged from ca. 30\% (Denmark, the Netherlands, the United Kingdom) to 60\% in Germany, and $75 \%$ in France. In Slovakia and the Czech Republic, it amounted to 78 and $88 \%$ respectively. Such a high share of leases in these countries resulted from the selected path of transformation of state-owned agriculture, which had been dominated by agricultural cooperatives and state-owned farms, subsequently transformed into private agricultural enterprises in the legal form of limited liability companies or cooperatives using the land through leasing it from previous owners or from the State Treasury. In comparison to other countries, the share of leased land in Poland is small. According to estimates, it amounts to ca. 20\%, including 11\% from the State Treasury assets (Statistisches Jahrbuch... 2011-2015).

\footnotetext{
${ }^{1}$ The parity revenue - the average income from labour in the national economy.

${ }^{2}$ An excessive level of intensity of production (mineral fertilisers and plant protection products) leads to harmful burden on natural environment - soil, water and air.
} 
Thanks to lease, the area of farms has increased. In 2010, the average farm area in countries such as: Denmark, France, Germany, Sweden and the United Kingdom, ranged from 43 hectares (Sweden) to 79 hectares (the United Kingdom). In 1960-2010, the area of farms has grown to the largest extent in Germany, more than sevenfold, from 7.9 hectares in 1960 to 55.8 hectares of agricultural area in 2010. Such a large increase of the average farm area was a result of Germany's unification in 1990. In Eastern Germany (former GDR) there had been large-area farms (agricultural cooperatives and state-owned farms), which retained their size despite restructuring. In the remaining countries (Denmark, France and Sweden) the area of farms increased more than three times. In the United Kingdom, the area of farms has doubled, however the initial value was higher: in 1960 it amounted to 41 hectares and was between two and four times higher than in the remaining countries. Against the background of the values given above, the average area of farms in Poland is exceptionally small. In 2010, it amounted to 6.4 hectares of agricultural land and was only $8 \%$ higher than in 1960. In 2015, it increased to 9.9 hectares of agricultural land (Ziętara, 2016). This low pace of increase of the average farm area in Poland is associated with the condition of Polish economy and its underdevelopment (Sikorska, 2013).

The primary factor influencing the scale of lease of agricultural land was prices, strongly diversified in the Western European countries mentioned above. They were highest in the Netherlands, where they amounted to EUR 53.2 thousand per hectare. In other countries: Western Germany (former FRG), Denmark and the United Kingdom, they were lower and amounted to respectively: EUR 28.43, 23.17 and 21.56 thousand per hectare; in France and Sweden they were several times lower and amounted to EUR 5.91 and 5.53 thousand per hectare respectively. Low prices of land in France result from strong administrative restrictions imposed on land market. In 2014, the prices of land in the Czech Republic, Slovakia and Poland amounted to respectively: EUR 5.07, 3.70 and ca. 7 thousand per hectare. In Poland, land prices were diversified due to the presence of the private market and sales of state-owned land, with prices on average lower by $20 \%$. Also, the increase of prices in the period under analysis should be emphasised. In Western European countries it ranged from $23 \%$ (Denmark) to $108 \%$ (Germany), while in Central and Eastern European countries and Eastern Germany (former GDR) it was higher, ranging from 212\% (the Czech Republic) to 320\% (Poland - the state market) and 313\% (former GDR) (Ziętara, 2016).

The claims presented above, namely that leasing agricultural land is gaining significance, provoke the question on efficiency of farming: lessees or land owners? The issues of ownership in the farming process were in the centre of interest of economists from the beginning of development of economics as a science. The heated dispute on the role of ownership has been going on for over 
200 years. Already in 1776, Adam Smith, recognised as the father of modern economics, formulated the following concept: "In any great monarchy in Europe, selling the Crown's land would bring much larger revenue to the Treasury than its exploitation so far (...). If the Crown's land became private, in a couple of years it would be significantly better fertilised and developed" (Begg, Fisher and Dornbusz, 1995).

The above idea indicates that an owner, farming at own risk and responsibility, follows to a larger extent the principle of rational farming, both in short and long term, than a hired administrator, farming at owner's risk. Smith's claims refer to farming "at own risk and responsibility". A lessee farms on own account on leased land. The assessment of efficiency of farming of a lessee can be effected through comparison with results achieved by a land owner operating a farm by own means. Pawlik (1922), when analysing the scope and significance of lease, points to its strengths and weaknesses. He believed that the biggest strengths of lease included:

- shaping more entrepreneurial, active and particularly "accounts-based" attitudes of farmers;

- a lessee with relevant qualifications farming rationally, better than a paid administrator.

Irrespective of advantages, Pawlik also points to weaknesses of lease:

- lease of land does not encourage incurring costs related to land improvement, such as amelioration of agricultural land, thus being to a certain extent a hindrance to increasing production;

- conditions of lease contract could limit the level of production intensity;

- there is a risk of overexploitation under lease, particularly in case of shortterm leases (1-3 years);

- lease does not encourage improvement of agricultural and rural culture, as a lessee is less interested in these issues than an owner settled in a given locality (Pawlik, 1922).

Also modern authors point to the problem of ownership, stating: "Plots, which are leased (whether by natural persons or cooperatives) have a relatively lower value than plots with the right of ownership, all other factors being equal" (Chonmert and Phelinas after: Czyżewski and Trojanek, 2016, p. 10). This claim supports an ambiguous thesis, according to which "the land with the ownership right is farmed better than leased land". Leased land is also owned (by owner), but not by lessee. For clarity, one should assume that the authors claim that a land owner, personally operating a farm, farms more effectively than a lessee.

In summary of the above considerations, the following question becomes valid: what is the efficiency of farming by lessees in comparison to owners personally running a farm. 


\section{The objective and methodology of the research}

The research aims to economically assess the efficiency of farming by lessees in comparison to owners running a farm. In pursuit of the objective of the study, the following working assumption has been made: "a lessee farms more effectively than an owner running a farm". This claim is supported by the assumption that results of lessee's farming are burdened with the cost of lease, the cost that is not borne by an owner. Moreover, a lessee bears higher risks, which forces him to more efficient farming, "with a pencil in hand" or - as Pawlik said - in a more "accounts-based manner".

The basis to verify the hypothesis is provided by the results of studies carried out by IERiGŻ-PIB since 1994 under "Ranking 300". The comparative studies cover farms of lessees and owners, who purchased previously leased farms. Farms with the share of leased land in the total area of land exceeding $50 \%$ have been considered to be leased farms. In order to eliminate the impact of farm's legal form on the results, the research covered private limited liability companies, with a further breakdown into those leasing land and those farming on their own land. The latter category has been further divided, based on the share of equity in liabilities - below and above $50 \%$. This delimitation has been necessary due to different levels of liability burden. Some farms had their own land, which was purchased with loans. Their situation in terms of liabilities is similar to farms leasing agricultural land. Due to their small number, this group has been excluded from further research. Farms were under research in 2009-2014. When assessing effectiveness of farming, the following profitability indices have been used: economic activity profitability ratio (ECPR), return on assets (ROA), return on equity (ROE), and value creation index (VCI). Moreover, financial security has been examined using the following indicators: current liquidity ratio (CLR), fast liquidity ratio (FLR), and financial results to total debt ratio (FRTDR). When calculating the values of indicators, the weighted arithmetic average and median have been used. In order to determine the materiality of differences between groups of farms, the Mann-Whitney $\mathrm{U}$ test has been employed.

\section{The characteristics of the research population of farms}

The research used empirical data collected from farms and used to create the ranking of 300 best agricultural enterprises in 2009-2014 (farms established in result of ownership transformations of former state-owned farms). In the period under analysis, both the size of the research sample and the size of individual sub-groups varied over time (Fig. 1), therefore the sample was not a panel sample.

This is because some companies were in the process of purchasing leased land, which depending on availability of equity on a farm resulted in it being moved to the group of farms with own land and primarily external capital (the 
intermediate group, excluded from the research) or to the group of farms primarily own capital (target research group of owners). Farms with purchased land but primarily external capital represent the population combining features of lessees and land owners. These farms, when making the purchase, guaranteed themselves with the right of possession of agricultural land, but made significant financial commitments (credits, long-term loans), thus taking substantial risks, resulting not only from the necessity to service the debt (the cost of interest and repayment of liabilities). For this reasons, the group was treated as a specific one and excluded from the research. Only those companies with purchased land whose equity finances at least half of the balance sheet assets have been included in the research.

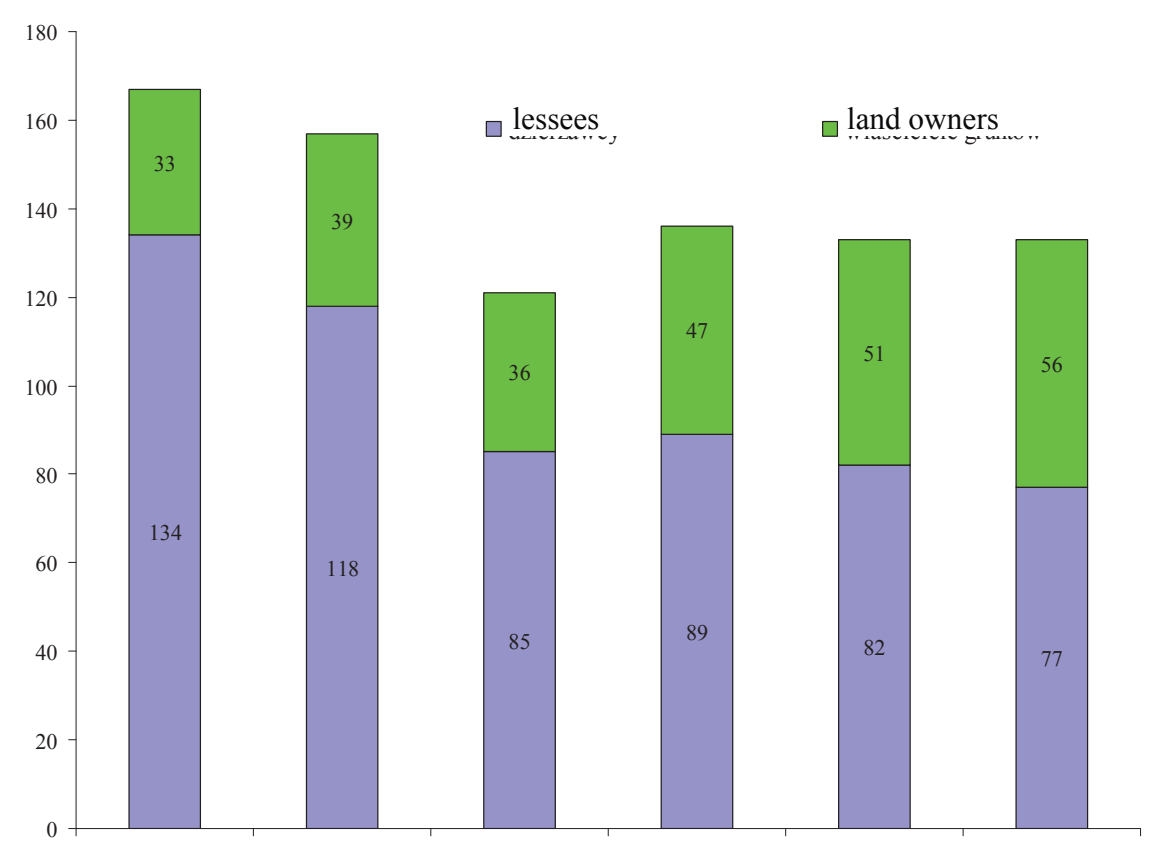

Fig. 1. The number of farms in individual groups researched in 2009-2014.

Source: own study.

Changes in the number of analysed farms in individual groups resulted from the processes of ownership and capital transformations, but also from the absence of continuity of research in some cases. This latter factor was particularly visible in the analysis of data from 2011. The deterioration of financial results in some companies not participating in the ranking for 2011 was observed, while they have sent data for subsequent years (participating in the research for 2012-2014). Several companies completely withdrew from the research in 2011. Thus the data facilitating the use of a panel of farms were not available, which 
made it difficult to draw conclusions for a time series. Therefore, the research focused on analysis of cross-sectional data.

The feature distinguishing individual groups of companies was the scale of production measured by the value of total revenue of given farms in a specific calendar year. Companies leasing land were characterised by larger revenues. The average value of total revenue in case of lessees ranged from PLN 10.5 million in 2009 to nearly PLN 15 million in 2014 (Table 1). Farms with purchased land lagged behind lessees in terms of this feature, as total revenues generated by these companies ranged from PLN 7.5 million in 2009 to PLN 10.9 million in 2014. On average, in the period under research, the value of total revenue on farms of lessees was ca. $18 \%$ higher than on owners' farms. This was due to area of farms being $44 \%$ larger, which was not compensated by revenues being $13 \%$ higher per 1 hectare of agricultural land on farms with own land.

The scale of activities was a derivative of the production means in farms' possession. On average, companies of lessees had $44 \%$ more agricultural land at their disposal. Farms from this group used ca. 1131 hectares of agricultural land, of which they owned only a small part (between 10\% in 2009 and $13 \%$ in 2014). On the other hand, the average area of owners' farms was 785 hectares, while the share of own land ranged from 51.9 to $100 \%$.

In the researched period, both researched groups had land of similar quality at their disposal. The soil classification indicator of utilised agricultural land was slightly higher on farms with purchased land, with the exception of 2009 and 2014. The level of employment per 100 hectares of agricultural land in both groups also varied over time. However, in case of this parameter the average employment level in the researched period was similar in both groups, i.e. 2.85 persons per hectare of agricultural land.

Companies, which were lessees, were characterised by higher capital-labour ratio - the value of assets per a full-time employed person. This pertained to both tangible assets (excluding land) and current assets. However, in 2009-2010, it were owners of land that were characterised by higher capital-labour ratio. This was caused by including the balance sheet value of land in the capital-labour ratio (empirical material facilitated definition of the value of this asset for researched companies only starting on 2011). 
Table 1

Revenue and availability of inputs in researched companies

\begin{tabular}{|c|c|c|c|}
\hline $\begin{array}{c}\text { Features of researched } \\
\text { companies (average) }\end{array}$ & Years & Land lessees & Mainly own land \\
\hline \multirow{6}{*}{ 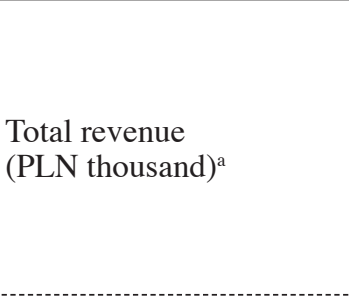 } & 2009 & 10446 & 7547 \\
\hline & 2010 & 11318 & 8790 \\
\hline & 2011 & 12391 & 11354 \\
\hline & 2012 & 14207 & 11920 \\
\hline & 2013 & 13502 & 11059 \\
\hline & 2014 & 14991 & 10937 \\
\hline \multirow{6}{*}{$\begin{array}{l}\text { Area of agricultural land } \\
{\text { (hectares })^{\mathrm{a}}}\end{array}$} & 2009 & 1083 & 951 \\
\hline & 2010 & 1119 & 735 \\
\hline & 2011 & 1223 & 794 \\
\hline & 2012 & 1105 & 807 \\
\hline & 2013 & 1047 & 744 \\
\hline & 2014 & 1211 & 677 \\
\hline \multirow{6}{*}{$\begin{array}{l}\text { Soil classification } \\
\text { index }(\ln )^{\mathrm{b}}\end{array}$} & 2009 & 1.04 & 0.97 \\
\hline & 2010 & 1.04 & 1.06 \\
\hline & 2011 & 1.01 & 1.08 \\
\hline & 2012 & 1.03 & 1.04 \\
\hline & 2013 & 1.02 & 1.05 \\
\hline & 2014 & 1.04 & 1.03 \\
\hline \multirow{6}{*}{$\begin{array}{l}\text { Employment level } \\
\text { per } 100 \text { hectares of } \\
\text { agricultural land } \\
(\text { person/100 hectares) }\end{array}$} & 2009 & 2.84 & 2.88 \\
\hline & 2010 & 2.95 & 2.80 \\
\hline & 2011 & 2.70 & 2.80 \\
\hline & 2012 & 2.69 & 2.53 \\
\hline & 2013 & 3.03 & 2.81 \\
\hline & 2014 & 2.94 & 3.27 \\
\hline \multirow{6}{*}{$\begin{array}{l}\text { Capital-labour ratio } \\
\text { (PLN thousand/person) }^{\mathrm{b}}\end{array}$} & 2009 & 404.7 & $489.6 c$ \\
\hline & 2010 & 420.8 & $519.6 \mathrm{c}$ \\
\hline & 2011 & 509.6 & 409.4 \\
\hline & 2012 & 605.8 & 459.3 \\
\hline & 2013 & 600.2 & 484.3 \\
\hline & 2014 & 649.0 & 432.9 \\
\hline
\end{tabular}

${ }^{\mathrm{a}}$ Arithmetic average; ${ }^{\mathrm{b}}$ weighted average calculated according to formula $1 ;{ }^{\mathrm{c}}$ value of balance sheet assets from 2011 adjusted with the value of own land (in 2009-2010 the balance sheet value of land belonging to researched companies was not available) per one full-time employee. Source: own study. 


\section{Economic efficiency of researched groups of farms}

The research analysed two areas of farms' economic efficiency: benefits achieved by owners and financial security of farms ${ }^{3}$. Profitability indices and value creation index were analysed in the first area, while liquidity ratios and the capacity to cover liabilities with net financial profit increased by depreciation - in the second.

From a mathematical point of view, the indicators used are quotients, thus they are relative numbers expressing a mutual relation of two statistical values (Twaróg, 2005). The research primarily uses weighted averages calculated for individual groups according to the formula:

$$
\bar{z}=\frac{\sum_{i=1}^{k} x_{i}}{\sum_{i=1}^{k} y_{i}}
$$

where:

$\bar{z}$ - weighted average of a given indicator,

$x_{i}$ - value of attribute $\mathrm{x}$ for $i$-th farm,

$y_{i}$ - value of attribute y fpr $i$-th farm,

$k$ - number of farms in a given researched group.

Thus calculated average measure takes into account the economic potential of researched entities and it is appropriate for calculating indicators (Sobczak, 2007). The measure facilitates the determination of existence of differences between groups of farms, but it does not facilitate such determination, if they are statistically significant. The research also uses a median as a measure of central tendency and the Mann-Whitney $U$ test in order to verify homogeneity of distribution of indicators in both research samples. The task of the applied nonparametric test was to confirm the null hypothesis on the absence of differences between economic results of land lessees and owners (H0:F1=F2 - samples coming from one population), with the alternative hypothesis on samples coming from different populations $(\mathrm{H} 1: \mathrm{F} 1 \neq \mathrm{F} 2)$. The application of non-parametric test was dictated not only by indicator analysis, but also by the fact that not all assumptions allowing for the application of the t-Student test were fulfilled throughout the research period (Rabie, 2012).

\footnotetext{
${ }^{3}$ This type of approach may be perceived as debatable. According to some approaches finances of enterprises do not constitute a part of economics. According to the authors, financial security is closely tied to economic efficiency of enterprises. Therefore, the two "areas" have been distinguished in the study of economic efficiency.
} 
Generally recognised financial indicators were used in researching economic efficiency of both groups of farms, including those used in Ranking 300 (Kagan and Kulawik, 2011), as well as the value creation index. In case of the latter, in order to estimate the cost of equity, M-M model (Modigliani and Miller) has been used, without income tax (Pomykalska and Pomykalski, 2007), with average two-year deposit interest rate as averaged cost of capital. On the basis of the calculated weighted average, one could draw a conclusion that the economic activity profitability ratio in most of analysed years (in four out of six) was at the higher level in the group of lessees than for farms with own land (Table 2). On this basis, one could assume that lessees typically achieve better results from operational activities. Of course this conclusion is not supported by any test and one cannot state if differences between groups are statistically significant.

However, the higher value of the median indicates that a larger share (in terms of numbers) of farms with domination of own land get better results at the operational level than lessees. The results of Mann-Whitney U test indicate that in 2010-2013 both groups substantially differed in terms of profitability of economic activity, and that the higher value of this indicator should be expected in the group of farms with purchased land.

However, in both cases the relations can be true, despite the impression on contradiction of results. The weighted average, taking into account the economic potential, means that the higher is the value of parameters of a given farm (in this case the total revenue and to a lesser extent the profit on economic activity), the larger is its weight in a given group. The largest companies, those with highest revenues and best net financial results, have the biggest impact, in extreme cases even dominating, on results in a given group, compared to small entities. Therefore, a higher weighted average may indicate that in the group of farms, run by lessees, a higher amount of net profit on economic activity was achieved per unit of revenue. On the other hand, the level of the median and the Mann-Whitney U test indicate that in the greater number of companies with purchased land the ECPR indicator was higher. In this last group, these were entities with a smaller scale of activities that achieved higher profitability of economic activity (Fig. 2), but due to their economic potential they had lesser impact on average results of the group they represented.

As regards profitability of total assets, almost throughout the entire research period (5/1 years) both the weighted average and the median were at higher levels in the group of farms with purchased land. However, in comparing the distribution of this indicator in both groups, it was not possible to reject the null hypothesis, assuming that the results came from samples belonging to one population. Thus the domination of farms with purchased land has not been confirmed statistically. However, the weighted average indicates that this group is characterised by a higher rate of return on a unit of capital. 
Table 2

Profitability indicators of researched companies in 2009-2014

\begin{tabular}{|c|c|c|c|c|c|}
\hline \multirow{2}{*}{\multicolumn{2}{|c|}{ Specification }} & \multicolumn{2}{|c|}{ Land lessees (group I) } & \multicolumn{2}{|c|}{ Own land (group II) } \\
\hline & & $\begin{array}{l}\text { Average } \\
\text { weighted }\end{array}$ & median & $\begin{array}{c}\text { Average } \\
\text { weighted }\end{array}$ & median \\
\hline \multirow{6}{*}{$\begin{array}{l}\text { Economic } \\
\text { activity } \\
\text { profitability } \\
\text { ratio }(\%) \\
(\text { EAPR })^{\mathrm{a}}\end{array}$} & 2009 & 10.53 & 7.59 & 8.35 & 12.03 \\
\hline & 2010 & 10.49 & 12.18 & 10.95 & 18.98 \\
\hline & 2011 & 14.61 & 16.17 & 13.80 & 22.46 \\
\hline & 2012 & 17.21 & 18.28 & 15.06 & 23.94 \\
\hline & 2013 & 9.16 & 7.99 & 9.61 & 13.03 \\
\hline & 2014 & 9.53 & 12.21 & 8.61 & 15.01 \\
\hline \multirow{6}{*}{$\begin{array}{c}\text { Return } \\
\text { on assets }(\%) \\
(\mathrm{ROA})^{\mathrm{b}}\end{array}$} & 2009 & 5.63 & 6.27 & 4.75 & 6.39 \\
\hline & 2010 & 8.58 & 9.87 & 8.84 & 7.93 \\
\hline & 2011 & 9.78 & 11.57 & 11.58 & 11.85 \\
\hline & 2012 & 12.63 & 14.19 & 13.65 & 15.26 \\
\hline & 2013 & 5.75 & 5.63 & 7.23 & 6.46 \\
\hline & 2014 & 5.36 & 6.55 & 6.53 & 6.60 \\
\hline \multirow{6}{*}{$\begin{array}{l}\text { Return } \\
\text { on equity }(\%) \\
(\mathrm{ROE})^{\mathrm{c}}\end{array}$} & 2009 & 9.17 & 10.51 & 5.83 & 7.83 \\
\hline & 2010 & 14.09 & 14.98 & 11.23 & 10.88 \\
\hline & 2011 & 15.38 & 17.81 & 15.17 & 17.33 \\
\hline & 2012 & 18.90 & 21.14 & 17.35 & 18.63 \\
\hline & 2013 & 8.16 & 8.11 & 9.33 & 7.85 \\
\hline & 2014 & 7.81 & 9.22 & 8.31 & 8.10 \\
\hline \multirow{6}{*}{$\begin{array}{l}\text { Value creation } \\
\text { index }(\ln ) \\
(\mathrm{VCI})^{\mathrm{d}}\end{array}$} & 2009 & 1.82 & 1.71 & 1.22 & 1.62 \\
\hline & 2010 & 3.23 & 3.27 & 2.81 & 2.41 \\
\hline & 2011 & 2.84 & 2.83 & 2.55 & 2.75 \\
\hline & 2012 & 3.75 & 3.80 & 2.95 & 3.31 \\
\hline & 2013 & 2.46 & 2.12 & 2.49 & 2.11 \\
\hline & 2014 & 2.15 & 2.59 & 2.26 & 2.21 \\
\hline
\end{tabular}

${ }^{a}$ The ratio of net financial result adjusted with the result from sales of non-financial assets to the total revenue; ${ }^{b}$ the quotient of net financial result adjusted with the result from sales of non-financial assets, and the total value of balance sheet assets at the end of the year; ${ }^{c}$ the ratio of net financial result adjusted with the result from sales of non-financial assets to equity at the end of the year; ${ }^{\mathrm{d}}$ the quotient of ROE and the cost of equity.

Source: own study. 


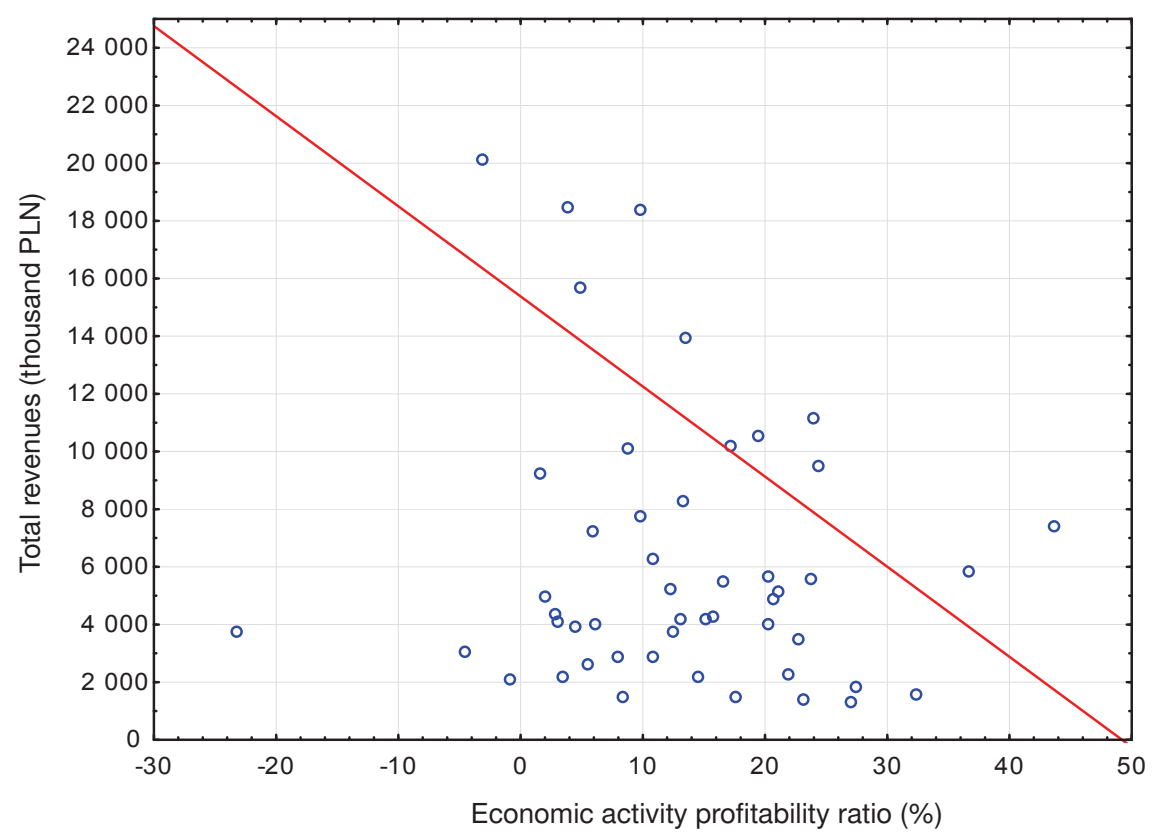

Fig. 2. The economic activity profitability ratio in 2013, depending on the size of total revenue generated by a company in the group of farms with purchased land.

Source: own study.

In most years (4/2 for weighted average) or in all years (for the median), lessees achieved higher values of return on equity indicator. This was a result of the financial leverage due to stronger involvement of external capital, not only in the form of leased land (off balance sheet capital), but also credits and loans, spreading the payment of liabilities over time, or merchant credit. The positive impact of such activities translated directly into the level of return on equity indicator.

However, the weighted average in 2013-2014 was higher for farms with domination of own land, but at the same time the distribution of companies pointed to a larger number of farms in this group achieving lower results. This was the result of larger entities - companies to which greater weight had been assigned - achieving higher return on equity. This is confirmed by the value of average higher than that of the median. In the course of the research, it was possible to confirm that the distribution of ROE differed significantly only in 2010. Thus it is only justified to claim with reference to this year that a larger number of lessees achieved higher level of ROE indicator and were more effective. 
Table 3

A list of results of the Mann-Whitney $U$ test for selected economic indicators ${ }^{a}$

\begin{tabular}{|c|c|c|c|}
\hline \multicolumn{2}{|c|}{ Specification } & \multicolumn{2}{|c|}{ Mann-Whitney U test } \\
\hline & & Value of test statistics & Statistical significance \\
\hline \multirow{4}{*}{$\begin{array}{l}\text { Economic activity } \\
\text { profitability ratio } \\
(\%)(\text { EAPR) }\end{array}$} & 2010 & $\mathrm{Z}=-2,21810$ & $\mathrm{p}=0,026549$ \\
\hline & 2011 & $Z=-2,46060$ & $\mathrm{p}=0,013871$ \\
\hline & 2012 & $Z=-2,02111$ & $\mathrm{p}=0.043269$ \\
\hline & 2013 & $\mathrm{Z}=-2,22583$ & $\mathrm{p}=0.026027$ \\
\hline $\begin{array}{l}\text { Return on equity } \\
(\%)(\mathrm{ROE})\end{array}$ & 2010 & $\mathrm{Z}=2,42935$ & $\mathrm{p}=0.015126$ \\
\hline \multirow{6}{*}{$\begin{array}{l}\text { Current liquidity } \\
\text { ratio (ln) (CLR) }\end{array}$} & 2009 & $Z=-3.27960$ & $\mathrm{p}=0.001000$ \\
\hline & 2010 & $Z=-2.25010$ & $\mathrm{p}=0.024400$ \\
\hline & 2011 & $Z=-2.60234$ & $\mathrm{p}=0.009260$ \\
\hline & 2012 & $Z=-2.35567$ & $\mathrm{p}=0.018490$ \\
\hline & 2013 & $Z=-2.67087$ & $\mathrm{p}=0.007566$ \\
\hline & 2014 & $\mathrm{Z}=-2.43811$ & $\mathrm{p}=0.028379$ \\
\hline \multirow{5}{*}{$\begin{array}{l}\text { Fast liquidity } \\
\text { ratio (ln) (FLR) }\end{array}$} & 2009 & $\mathrm{Z}=2.29890$ & $\mathrm{p}=0,021500$ \\
\hline & 2011 & $Z=-2.27350$ & $\mathrm{p}=0.022997$ \\
\hline & 2012 & $Z=-2.40150$ & $\mathrm{p}=0.016329$ \\
\hline & 2013 & $Z=-2.98867$ & $\mathrm{p}=0.002802$ \\
\hline & 2014 & $Z=-2.43811$ & $\mathrm{p}=0.014765$ \\
\hline \multirow{5}{*}{$\begin{array}{l}\text { Financial results } \\
\text { to total debt ratio } \\
\text { (ln) (FRTDR) }\end{array}$} & 2009 & $Z=-2.95800$ & $\mathrm{p}=0,003100$ \\
\hline & 2010 & $Z=-2.25420$ & $\mathrm{p}=0.024200$ \\
\hline & 2011 & $Z=-1.96734$ & $\mathrm{p}=0.049144$ \\
\hline & 2012 & $Z=-2.33734$ & $\mathrm{p}=0.019422$ \\
\hline & 2013 & $\mathrm{Z}=-2.37177$ & $\mathrm{p}=0.017704$ \\
\hline
\end{tabular}

${ }^{a}$ Only results were presented, for which the level of significance was $\mathrm{p} \leq 0.05$.

Source: own study.

The value creation index is the most important one from the point of view of the hierarchy of indicators illustrating benefits gained by the owner. However, in the research carried out it turned out to be a derivative of ROE. When analysing the weighted average, it has been concluded that, with the exception of 2013-2014, its level was higher for lessees, while the level of the median - almost throughout the entire researched period. The Mann-Whitney U test has not confirmed the hypothesis on a diversified distribution of this indicator in researched groups. The groups did not differ in terms of the number of companies achieving a specific VCI level. 
However, it is not possible to undermine the hypothesis saying that farms with purchased land are characterised by higher level of financial security than those operated by lessees. Both liquidity indicators and financial results to total debt ration confirm this (Table 4).

Table 4

Financial security indicators of researched companies in 2009-2014

\begin{tabular}{|c|c|c|c|c|c|}
\hline \multirow[b]{2}{*}{ Specification } & & \multicolumn{2}{|c|}{ Land lessees } & \multicolumn{2}{|c|}{ Own land } \\
\hline & & $\begin{array}{l}\text { Average } \\
\text { weighted }\end{array}$ & median & $\begin{array}{l}\text { Average } \\
\text { weighted }\end{array}$ & median \\
\hline \multirow{6}{*}{$\begin{array}{l}\text { Current liquidity ratio } \\
\text { (ln) (CLRa }\end{array}$} & 2009 & 2,13 & 3,17 & 4,52 & 7,15 \\
\hline & 2010 & 2,20 & 3,03 & 4,14 & 7,39 \\
\hline & 2011 & 2,27 & 3,53 & 4,47 & 7,75 \\
\hline & 2012 & 2,58 & 4,86 & 4,85 & 7,22 \\
\hline & 2013 & 2,75 & 4,71 & 5,21 & 6,83 \\
\hline & 2014 & 2,34 & 5,99 & 5,30 & 7,37 \\
\hline \multirow{6}{*}{$\begin{array}{l}\text { Fast liquidity ratio } \\
(\ln )(\text { FLR })^{b}\end{array}$} & 2009 & 0,99 & 1,41 & 1,68 & 2,42 \\
\hline & 2010 & 1,07 & 1,63 & 2,16 & 2,63 \\
\hline & 2011 & 1,01 & 1,70 & 2,41 & 4,07 \\
\hline & 2012 & 1,16 & 1,93 & 2,48 & 4,31 \\
\hline & 2013 & 1,19 & 1,92 & 3,04 & 4,17 \\
\hline & 2014 & 0,91 & 2,18 & 3,00 & 3,82 \\
\hline \multirow{6}{*}{$\begin{array}{l}\text { Financial results } \\
\text { to total debt ratio } \\
(\ln )(\text { FRTDR })^{c}\end{array}$} & 2009 & 0,26 & 0,31 & 0,53 & 0,55 \\
\hline & 2010 & 0,34 & 0,48 & 0,68 & 0,77 \\
\hline & 2011 & 0,39 & 0,47 & 0,71 & 0,81 \\
\hline & 2012 & 0,52 & 0,64 & 0,86 & 1,01 \\
\hline & 2013 & 0,34 & 0,39 & 0,53 & 0,53 \\
\hline & 2014 & 0,30 & 0,38 & 0,52 & 0,51 \\
\hline
\end{tabular}

a The ratio of current assets at year end, minus short-term accruals, to short-term liabilities; ${ }^{\mathrm{b}}$ the quotient of current assets, minus stocks and short-term accrual, to short-term liabilities at year end; ${ }^{\mathrm{c}}$ the ratio of the amount of net financial result, adjusted by the result from sales of non-financial assets, and depreciation and total liabilities of the enterprise at year end.

Source: own study.

In the entire researched period land lessees achieved lower level of the average and median than the group II. The statistical test has confirmed that in terms of all three indicators, farms with purchased land were the group, in which a greater number of companies were characterised by better parameters. 


\section{Summary}

On the basis of the research, it has been concluded that in the period under analysis, a larger number of farms with purchased land were characterised by higher profitability of economic activity in relation to lessees. In all years, except of 2009 and 2014, the differences in the distribution of companies in terms of the indicator were significant, which was confirmed by statistical tests. This results from the fact that the financial results of a greater number of companies from this group are much less burdened with the costs of both lease and the cost of external capital servicing. However, the advantage of this group is due primarily to better economic results of smallest entities. In a longer time perspective, the level of weighted average of this indicator was higher for lessees. This points to better results on primary operations achieved by relatively large companies. Thus, despite the fact that for a larger number of farms with own land the EAPR indicator was substantially higher, the leased farms achieved on average a higher net profit on economic activity per unit of revenue.

The advantage of land owners has been shown in analysis of return on assets. On average, farms from this group achieved better returns per unit of asset value, but at the same time it has not been confirmed that ROA was at a significantly higher level in a larger number of these companies.

Lessees, in turn, benefited from the effect of financial leverage to a much larger extent, due to a greater involvement of external capital in financing their activities. Thanks to this, in most of years under research, companies from this group achieved on average a higher level of return on equity and value creation index. On the basis of ROE distribution, only for data for 2010, it was possible to confirm substantial advantage of lessees in this area of economic efficiency.

The research has demonstrated that there is no statistical evidence supporting the claim that lessees farm less financially efficiently than farms with purchased land, or to the contrary - that they achieve better economic results. Such claim is justified only at the level of profitability of economic activity that is at the level of the indicator, which is the lowest in the hierarchy of relevance in the analysis of benefits resulting from owning a farm.

In most years, lessees showed higher levels of ROE and value creation index. Despite the fact that their advantage (in terms of the number of farms) has not been confirmed statistically, a higher level of economic efficiency has been identified in the group in question in this research area. The capping mechanism introduced in 2015 , limiting the amount of the single direct payment for the largest beneficiaries of budgetary support, will probably translate into deterioration of results from other operational activities, thus changing all 
remaining profitability indicators (except return on sales) and financial security indicators.

The research has confirmed that farms with own assets are characterized by significantly higher level of financial security. Thus, their advantage in this area of analysis is substantial. 


\section{References}

Begg, D., Fischer, S., Dornbusz, R. (1995). Ekonomia. Warsaw: PWE.

Czyżewski, B., Trojanek, R. (2016). Czynniki wartości ziemi rolnej w kontekście zróżnicowanych funkcji obszarów wiejskich w Polsce. Problems of Agricultural Economics, No 2(247), p. 3-25.

CSO. Statistical Yearbooks, 1960-2015. Warsaw.

CSO. Agriculture Statistical Yearbooks. 2006-2014. Warsaw.

Kagan, A., Kulawik, J. (2011). Ranking przedsiębiorstw (gospodarstw) rolniczych: istota, konstrukcja i kierunek analizy. Komunikaty, Raporty, Ekspertyzy, no. 550. Warsaw: IERiGŻ-PIB.

Pawlik, S. (1922). Dzierżawa i umowa dzierżawna. Warsaw: Księgarnia Rolnicza.

Pomykalska, B.,Pomykalski,P.(2007). Analiza finansowa przedsiębiorstw. Warsaw: Wydawnictwo PWN.

Rabie, M. (2012). Statystyka z programem Statistica. Warsaw: Wydawnictwo Helion.

Rynek ziemi rolniczej. Stan i perspektywy. Analizy Rynkowe, no. 14/2011 and 18/2015, Warsaw: IERiGŻ-PIB.

Sikorska, A. (2013). Przemiany w strukturze agrarnej indywidualnych gospodarstw rolnych. Warsaw: IERiGŻ-PIB.

Sobczak, M. (2007). Statystyka. Warsaw: Wydawnictwo Naukowe PWN.

Statistisches Jahrbuch über Ernährunug, Landwirtschaft und Forsten 2009-2014 (2011-2015). Münster: Landwirtschaftsverlag.

Twaróg,J.(2005). Mierniki i wskaźniki logistyczne.Poznań: Instytut Logistyki i Magazynowania.

Ziętara, W. (2016). Dzierżawa ziemi w gospodarstwach rolniczych jako podmiotach biogospodarki. Roczniki Naukowe Seria, v. XVIII, b. 3, p. 303-309. 


\title{
ADAM KAGAN
}

WOJCIECH ZIECTARA

Instytut Ekonomiki Rolnictwa i Gospodarki Żywnościowej

- Państwowy Instytut Badawczy

Warszawa

\section{EKONOMICZNA EFEKTYWNOŚĆ GOSPODAROWANIA - DZIERŻAWCA CZY WŁAŚCICIEL (PRÓBA OCENY)}

\begin{abstract}
Abstrakt
$W$ artykule przedstawiono role $i$ znaczenie dzierżawy ziemi $w$ przemianach strukturalnych $w$ rolnictwie $i$ jej zwiazek z efektywnościa gospodarowania. Wykazano, że dzierżawa ziemi była skuteczniejszym i tańszym sposobem zwiększania powierzchni gospodarstw (skali produkcji) niż zakup ziemi. Badania przeprowadzono na wybranych grupach spótek z o.o. użytkujacych grunty dzierżawione (I grupa) $i$ własne (II grupa), bioracych udziat $w$ Rankingu 300 prowadzonym przez IERiGŻ-PIB w latach 2009-2014. Wyniki badań wskazały, że gospodarstwa prowadzone przez dzierżawców osiagały wyższa rentowność kapitałów własnych i indeksu tworzenia wartości. Różnice nie zostały jednak potwierdzone statystycznie, co oznacza, że nie były istotne. Natomiast gospodarstwa użytkujace grunty własne wykazały sie wyższym poziomem bezpieczeństwa finansowego, o czym świadcza wyższe wartości wskaźników płynności (bieżacej i szybkiej) i wskaźnika pokrycia zobowiazań nadwyżka finansową. Nie została w pełni potwierdzona hipoteza, $\dot{z}$ e „dzierżawca gospodaruje efektywniej niż właściciel”.
\end{abstract}

Słowa kluczowe: gospodarstwa rolnicze, dzierżawa ziemi, efektywność ekonomiczna, bezpieczeństwo finansowe.

Accepted for print: 16.10.2017.

Unless stated otherwise all the materials on the website are available under the Creative Commons Attribution 3.0 Poland license. Some rights reserved to the Institute of Agricultural and Food Economics - National Research Institute.

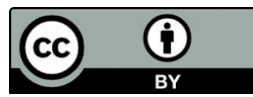

